\title{
Essay
}

\section{The Legal Adviser's Duty to Explain}

\author{
Harold Hongju $\mathrm{Koh}^{\dagger}$
}

INTRODUCTION.

I. ORIGINS

II. CONTRoversial CASES

III. ANSWERING OBJECTIONS.

\section{INTRODUCTION}

A great deal has been written about both international law and government lawyering. ${ }^{1}$ Most of it has focused on a government legal adviser's duties to give confidential advice to his or her principal, Secretary, Minister, or agency; his or her role in negotiation and litigation; and efforts among legal advisers to develop national and international networks to improve their effectiveness. Too little has been written about the crucial, overlooked responsibility of government international lawyers to explain publicly their government's international law rationale for its actions: what I call "The Legal Adviser's Duty to Explain."

As I suggested five years ago, the Legal Adviser's Duty to Explain is a loyalty that government legal advisers owe not just to their clients and ministers but also to their publics and national citizenries. ${ }^{2}$ Under this important

$\dagger \quad$ Sterling Professor of International Law, Yale Law School; Legal Adviser, U.S. Department of State, 2009-2013. This Essay grows out of a chapter from THE ROLE OF LEGAL ADVISERS IN INTERNATIONAL LAW (Andraz Zidar \& Jean-Pierre Gauci eds., forthcoming 2016) (hereinafter Zidar \& Gauci] and remarks given at a conference held by the British Institute of International and Comparative Law on February 26, 2015, at the Foreign and Commonwealth Office, London, on the 100th Anniversary of the Founding of the Grotius Society. The views expressed here are my own and do not necessarily represent the views of any past or present employer. I am grateful to Daniel Bethlehem, Sarah Cleveland, Joel Goldstein, Rebecca Ingber, Gerry Neuman, Alexandra Perina, Phil Spector and Dakota Rudesill for their help and to Jacqueline Van De Velde, Yale Law '17, and Sophia ChuaRubenfeld, Yale Law '18, for their excellent research assistance.

1. See generally MichaEl P. Scharf \& PAUl R. WILliams, Shaping Foreign

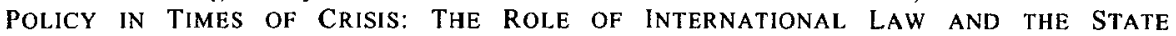
Department Legal AdViSER (2010) [hereinafter Scharf \& WiLliaMs]; Antonio Cassese, The Role of the Legal Adviser in Ensuring that Foreign Policy Meets International Legal Standards, 14 MiCH. J. INT'L L. 139 (1992); Harold Hongiu Koh, The State Department Legal Adviser's Office: Eight Decades in Peace and War, 100 GEO. L.J. 1747, 1754 (2012) [hereinafter Koh, Eight Decades] (part of this Essay deriving from this article); Zidar \& Gauci, supra note $\dagger$.

2. See Harold Hongju Koh, Legal Adviser, U.S. Dep't of State, Remarks at the Annual 
transparency norm, senior government lawyers, and the Legal Adviser of the foreign ministry, in particular, should be expected not just to give legal advice in private but also to explain in public the international legal basis supporting the action that their government has taken.

Fulfilling this duty is particularly important with respect to international law. To participate in a system of international law, nations owe each other explanations of why they believe their national conduct comports with global norms and follows not from mere expedience but from a sense of legal obligation (opinio juris). By laying out her government's legal theory in public, the legal adviser shoulders the nation's responsibility to give its citizens, the media, legal commentators, and legislators, as well as the international legal community, a fuller opportunity to assess the legal theory offered to authorize a given action and to test the government's present and future actions in light of that theory.

This Essay explores the history and virtues of the Duty to Explain from the perspective of America's national experience. In arguing for a Duty to Explain, I generalize from my own experience as the twenty-second Legal Adviser of the U.S. Department of State: an unusually large legal office whose unique institutional history $I$ and others have reviewed elsewhere. ${ }^{3}$ Undeniably, other nations' legal advisers may operate under greater strictures that prevent them from speaking as publicly as their American counterparts. In some countries, public legal explanations traditionally come from only one source-the office of the Prime Minister or the Attorney General, for example. ${ }^{4}$ I offer these thoughts in the hope that they will inspire other legal advisers and international legal scholars to reflect on their own national experiences and to offer their own national examples of how considered public legal explanation can enhance the legitimacy and sustainability of controversial public actions. I close by answering common objections to the notion of a public duty, concluding that broader recognition and study of such a public Duty to Explain would be both legally useful and politically prudent.

\section{ORIGINS}

For any United States government lawyer, discussion of a public Duty to Explain begins with the historic opinion-giving function of America's Attorney General. ${ }^{5}$ The United States Congress's First Judiciary Act, enacted in 1789, famously created the Office of the Attorney General, a person "learned in the law," charged with the duty "to give his advice and opinion upon questions of law when required by the President of the United States, or when requested by the heads of any of the departments, touching any matters that may concern

Meeting of the American Society of International Law (Mar. 25, 2010), http://www.state.gov/s///releases /remarks/139119.htm [hereinafter Koh Remarks at ASIL]; Koh, Eight Decades, supra note 1, at 1754.

3. See generally SCHARF \& WILlIAMS, supra note 1; Koh, Eight Decades, supra note 1.

4. See, e.g., John L. J. Edwards, The AtTorney General, Politics, and the PUBLIC INTEREST 181 (1984) (discussing British practice regarding public legal explanations). 2015).

5. About DOJ, U.S. DEP'T OF JUST., http://www.justice.gov/about (last visited Nov. 22 , 
their departments." ${ }^{.6}$ As that office's workload multiplied, Congress passed the Act to Establish the Department of Justice as "an executive department of the government of the United States," with the Attorney General as its head. ${ }^{\text {? }}$

What was less clear was who was to opine authoritatively to other parts of the U.S. government and the outside world regarding questions of international law. For the first sixty years of the Republic, the early Secretaries of StateThomas Jefferson, James Madison, and James Monroe-did their own international legal work, as one might have expected from diplomats and statesmen so well-versed in the law of nations. As the Statute of the International Court of Justice came to acknowledge, "the teachings of the most highly qualified publicists of the various nations [are treated] as subsidiary means for the determination of rules of law." 8 The reasoning behind this rule, historian Francis Wharton suggested in the mid-nineteenth century, was that "the opinions of . . . Secretaries of State, coupled with those of our Presidents as to which they were naturally consulted, form a body of public law which will stand at least on a footing of equality with the state papers of those of foreign statesmen and jurists."

By the mid-nineteenth century, "citizen-to-state claims"-claims by U.S. citizens against foreign states and vice versa-had proliferated to the point that they threatened to overwhelm the Secretary and his small staff. This led in 1848 to the creation of the position of "Claims Clerk," who would give legal advice to the State Department with regard to such citizen-state claims, a job superseded some twenty years later by the position of "Examiner of Claims.", When the Department of Justice was established in 1870, the Examiner of Claims was placed under the Attorney General's supervision. ${ }^{11}$ But soon, the Examiner's work extended beyond simple claims to such broader questions of private and public international law as citizenship, the laws of war, and the laws of prize, as well as boundary disputes and treaty interpretation.

By 1891, the Examiner of Claims had become known as the State Department's "Solicitor," who-although still a Department of Justice employee-functioned for four decades as an external law officer for the State Department. On February 23, 1931, Congress enacted the Moses-Linthicum Act, which abolished the Office of the Solicitor and created the State

6. Judiciary Act of 1789 , ch. $20, \S 35,1$ Stat. $73,92-93$ (codified at 28 U.S.C. $\S \S 511-13$ ). Pursuant to 28 U.S.C. $\S 510$, the Attorney General has now delegated to the Office of Legal Counsel, the general counsel's office for the Department of Justice, responsibility for preparing the formal opinions of the Attorney General and assisting the Attorney General in the performance of his core functions as legal adviser to the President. See 28 C.F.R. $§ 0.25$ (1988).

7. Act to Establish the Department of Justice, ch. 150, 16 Stat. 162 (1870).

8. Statute of the International Court of Justice art. 38, June 26, 1945, 59 Stat. 1055, 33 U.N.T.S. 993.

9. A Digest of the INTERnational LaW OF THE UNITED STATES TAKEN From Documents Issued by Presidents and Secretaries of State, and from decisions of FEDERAl COURTS AND OPINIONS OF ATTORNEYS GENERAL, at v (Francis Wharton ed., U.S. Gov't Printing Office 1886) [hereinafter WHARTON'S DIGEST].

10. Legal Advisers, OFF. OF THE HISTORIAN, U.S. DEP'T OF STATE, https://history.state .gov/departmenthistory/people/principalofficers/legal-adviser (last visited Jan. 6, 2016).

11. See Richard B. Bilder, The Office of the Legal Adviser: The State Department Lawyer and Foreign Affairs, 56 AM. J. INT'L L. 633, 634 (1962). 
Department's current Office of the Legal Adviser. ${ }^{12}$ The statute pointedly spelled "Adviser" with an "e," paying homage to the position's ancestral cousin: "The Legal Adviser" of the Foreign and Commonwealth Office of Her Majesty's Government.

Thus, at this writing, "L"-as the Legal Adviser's Office is commonly known within the United States Government-and its ancestors have been for nearly 170 years the Executive Branch's primary agent, authority, and focal point for international law. In that capacity, $L$ is charged with figuring out how to formulate and implement the foreign policies of the United States in accordance with international law and the responsible development of international institutions. Among other duties, L helps determine how international agreements should be crafted, how international organizations should be structured, and how customary international law rules should be interpreted and articulated.

As I have elsewhere summarized, the State Department's Legal Adviser simultaneously plays many roles. Ideally, the Legal Adviser should act as an independent, nonpartisan expert on and scholar of international law, with a wide-ranging remit across the Department's entire workload, always giving legal advice that is sensitive to the clients' policy objectives, taking the long view, and seeking to advance the best long-term interests of the State Department as an institution rather than the interests of any particular individual or administration. These competing commitments require the Legal Adviser to balance the concerns of politics and the law, to report directly to the Secretary (with career lawyers in turn reporting directly to the Legal Adviser), and to run an office of professional international lawyers that is kept in the loop with regard to all departmental matters. $L$ must be in at the takeoff of a new foreign policy episode to help establish the legal and political legitimacy of the actions that follow. At the same time, $\mathrm{L}$ must also stay connected to the outside world, including the legal academy, which both reinforces the Legal Adviser's Duty to Explain and underscores the capacity of U.S. Executive Branch lawyers not just to interpret but more fundamentally to shape international law. In all of this work, L plays many roles, not only as a desk-bound interpreter but also as an action officer, negotiator, litigator, counsel to diplomatic litigation, architect of new legal institutions, and at times arbiter of international legal disputes. ${ }^{13}$

While this compressed history explains the origins of the Legal Adviser's confidential opinion-giving function, what is harder to trace is when this function extended into a public Duty to Explain. As Kennedy Administration Legal Adviser and Harvard Law Professor Abram Chayes put it, "whether we [Americans] will profess to live by the law is not an issue of policy on which we have alternatives. The answer is inherent in our national tradition, in our culture, and it is implicit in our avowal at birth of 'a decent respect for the

12. Moses-Linthicum Act, Pub. L. No. 71-715, § 30, 46 Stat. 1207, 1214 (1931) (establishing the Foreign Service of the United States of America).

13. Koh, Eight Decades, supra note 1, at 1756-57. 
opinion of mankind." "14 By so saying, Professor Chayes expressly invoked the notion embedded in the U.S. Declaration of Independence, which obliged our new nation - in paying "decent respect to the opinions of mankind"- to give public reasons explaining to the world why its secession from England was lawful and legitimate. ${ }^{15}$ Thus, even at its founding, the United States perceived a national obligation to make public the basis for its international legal actions.

The tradition of public explanation became prominent in the nineteenth century, when British forces preemptively attacked forces on the American side of the Saint Lawrence River. The ensuing negotiations in the Caroline case, which led to the Webster-Ashburton Treaty of 1842, prompted then-U.S. Secretary of State Daniel Webster, a distinguished lawyer and Supreme Court advocate, to offer what has since become the classic international law definition of self-defense: a government that claims self-defense as the justification of a use of force must "show a necessity [that is] ... instant, overwhelming, leaving no choice of means, and no moment for deliberation." 16

By 1877, Assistant Secretary of State John Lambert Cadwalader-later co-founder of the famous New York law firm Cadwalader, Wickersham \& Taft - had compiled a comprehensive Digest of the International Law of the United States, taken from published Opinions of Attorneys General and the leading decisions of the federal courts. ${ }^{17}$ By 1886 , Francis Wharton had compiled an even more comprehensive Digest of the International Law of the United States, taken not just from judicial decisions and Attorney General opinions but also from historical documents issued by Presidents and Secretaries of State. In Wharton's words, his Digest summarized "not merely the messages of our Presidents, but the volumes, now nearly four hundred in number, in which are recorded . . the opinion of our Secretaries of State, offering the U.S. government's official public legal rationales for a large number of the U.S. government's historic actions.

In 1906, an extraordinary group of public figures-including former State Department Solicitor James Brown Scott, President William Howard Taft, former Secretary of State Elihu Root, Governor-Elect of Connecticut Simeon Baldwin, former Ambassador to Great Britain Joseph Choate, millionaire philanthropist Andrew Carnegie, and President Emeritus of Harvard Charles Eliot-founded a learned society, the American Society of International Law,

14. Abram Chayes, Progress Towards International Law, 55 PROC. OF THE AMERICAN SOC'Y OF INT'L L. AT ITS ANN. MEETING (1921-1969) 202, 205 (1961) (printing remarks made by Abram Chayes on April 29, 1961, during his time as Legal Adviser at the U.S. Department of State).

15. THE DECLARATION OF INDEPENDENCE (U.S. 1776). Some twenty years later, I invoked the Declaration's explanation to argue in support of the legality of Kosovo's Declaration of Independence before the International Court of Justice. See Harold Hongju Koh, Legal Adviser, U.S. Dep't of State, on behalf of the United States of America, Oral Observations of the International Court of Justice: On the Accordance with International Law of the Unilateral Declaration of Independence by the Provisional Institutions of Self-Government of Kosovo, 14 (Dec. 8, 2009), http://www.icj-cij.org/docket/files/141 /15726.pdf.

16. Daniel Webster, Letter to Henry Stephen Fox, in 1 ThE PAPERS OF DANiEL WeBSTER: Diplomatic PAPERS, 1841-1843, at 58 (Kenneth E. Shewmaker ed., 1983).

17. WHAR'TON'S DIGEST, supra note 9.

18. Id. at iv-v. 
which the following year began the quarterly publication of the American Journal of International Law. ${ }^{19}$ One focus of the journal was to highlight official U.S. government explanations of legal conduct. This point was underscored in former Secretary of State Elihu Root's opening article in the very first issue of the Journal in 1907, entitled "The Need of Popular Understanding of International Law." ${ }^{20}$ Root made explicit that public explanation of international law arguments was critical to the popular understanding necessary to ensure informed democratic oversight of national conduct abroad: "The increase of popular control over national conduct, which marks the political development of our time, makes it constantly more important that the great body of the people in each country should have a just conception of the international rights and duties." 21

By so saying, Secretary Root prefigured what I have dubbed the concept of "norm-internalization" as a central reason why nations obey international law"

[T] he true basis of the peace and order in which we live is not fear of the policeman; it is the self-restraint of the thousands of people who make up the community and their willingness to obey the law and regard the rights of others.

Obviously, the people who make up the "international law community" cannot exercise such self-restraint unless they understand-and accept as legitimate-their government's public rationales for why particular actions are lawful.

Along with the quarterly publication of the American Journal, the public tradition of presenting the U.S. government's international legal rationales continued in the eight-volume work of John Bassett Moore, Wharton's assistant, who first offered his own Digest in $1906 .^{25}$ Wharton's and Moore's tradition of public explanation was then carried forward for decades first by the Digests of International Law edited by long-time Legal Adviser (and later International Court of Justice Judge) Green Hackworth and then by long-time Assistant Legal Adviser and Counselor Marjorie Whiteman. ${ }^{26}$ By 1962, future Professor Richard Bilder could write: "The number of international law questions passed on by international or United States tribunals is probably no more than a fraction of the number of such questions passed on by the Office of

19. See generally MARK W. JANIS, THE AMERICAN TRADITION OF INTERNATIONAL LAW: GREAT EXPECTATIONS 1789-1914, at 152 (2004).

20. Elihu Root, The Need of Popular Understanding of International Law, 1 AM. J. INT'L L. 1 (1907).

21. Id.

22. Cf. Harold Hongju Koh, Why Do Nations Obey International Law?, 106 Y ALE L.J. 2599, 2601-02 (1997) (reviewing ABRAM CHAYES \& ANTONIA HANDLER CHAYES, THE NEW SOVEREIGNTY: COMPLIANCE WITH INTERNATIONAL REgUlatory AGREEMENTS (1995) and THOMAS M. FranCK, FAIRNESS IN INTERNATIONAL LAW AND INSTITUTIONS (1998)) (describing norm-internalization as the key to a transnational legal process approach).

23. Root, supra note 20 , at 2.

24. Cf. TOM Tyler, Why PEOPle OBey The LAW (2006) (arguing that people obey the law because they believe it is legitimate, not because they fear coercion or punishment).

25. See John BassetT MOORE, 1906-14 Digest of INTERnational LAW; see also JANIS, supra note 19, at 124 n.45.

26. See GreEn H. Hack Worth, 1937-43 Digest of InTERnational Law; Marjorie M. WhITEMAN, 1963-72 DIGEST OF INTERNATIONAL LAW. 
the Legal Adviser in any equivalent period, and the types of such questions considered by courts are generally of comparatively minor significance in the broad context of international regulation.,27

As a general matter, the State Department's justifications continue to be publicly available today in the Digest of the United States Practice in International Law, published annually by the Office of the Legal Adviser. ${ }^{28}$ Sometimes the legal rationales are brief, and rarely are they tested before and definitively resolved by courts. But as Abram Chayes argued, this tradition of public justification has fostered both internal self-criticism and external accountability over the years:

\begin{abstract}
If there can be no determinate answer [in international law], analysis and criticism can nevertheless distinguish a persuasive from a specious rationale, a responsible and serious performance from a trivial one. In this way, the requirement of justification provides an important substantive check on the legality of action and ultimately on the responsibility of the decision-making process.
\end{abstract}

\title{
II. Controversial Cases
}

In my experience, government officials almost always believe their actions are necessary, correct, and lawful. Providing a public justification is a necessary step to explain why others should agree that actions taken by those government officials are consistent with international law. As a prudential matter, such public explanations prove to be critically important in bringing along the rest of the country and prospective allies in establishing the legitimacy of a public action. There is an understandable tendency to limit such public explanations when the government action is controversial or when the facts on the ground are changing quickly. But the more controversial the action, the more a swift and thorough public explanation is needed, so that the media, academic community, branches of government other than the executive, and others who will be affected can assure themselves that the government action is indeed justified under international law.

Still, the notion of a Legal Adviser's Duty to Explain raises delicate questions of who, when, and what: who should give the public explanation, when should it be given, and what should it address? While the Legal Adviser of the State Department may be the logical person to address publicly the international legal rationale for many foreign policy actions, depending on the overlap with other agency's portfolios, other government legal advisers of comparable rank, or their policy clients, may also end up publicly enumerating these legal rationales. For example, over a five-year period, the Obama Administration's legal rationale for America's post-9/11 use of force has been publicly set forth in a series of speeches, including several by various agency

27. Bilder, supra note 11 , at 668 .

28. See Digest of United States Practice in International Law, U.S. DEP'T STATE, http:// www.state.gov/s/l/c8183.htm (last visited Nov. 22, 2015).

29. Abram Chayes, The Cuban Missile Crisis: InTERnational Crises and the ROLE OF LAW 42 (1974). 
general counsels. ${ }^{30}$

The manner in which the legal adviser gives a public interpretation of the United States's position under international law heavily depends on context and role: particularly whether the Legal Adviser is playing the role of counselor, conscience, defender, or spokesperson for his or her government on international law. ${ }^{31}$ The first two roles tend to be quiet ones. As a counselor, like any other public or private general counsel, the Legal Adviser quietly gives formal and informal legal advice to help clients achieve their policy objectives, applying a complex admixture of law that includes U.S. constitutional provisions, statutes, regulations, judicial decisions, past executive precedents, treaty commitments, and customary international law. As a conscience, the Legal Adviser gives prescriptive advice and strives not just to guide difficult policy choices into lawful channels but also to suggest that certain choices may be "lawful but awful," i.e., legally permitted but unwise or foolish as a matter of policy. But as a defender or spokesperson, the legal adviser plays a more vocal role. As a defender of U.S. interests, the Legal Adviser represents the United States in treaty negotiations, diplomatic discussions, and international litigation before all manner of international tribunals. In this role, the legal adviser also coordinates daily with the Department of Justice on litigation before domestic tribunals. And as spokesperson, the Legal Adviser speaks for the U.S. government regarding the meaning and interpretation of a particular issue of international law.

It is in these latter two capacities-defender and spokespersonparticularly in complex, delicate, and contentious cases where legal issues bleed into moral and policy issues, that a Legal Adviser's public statements play a critical role in placing legal issues within their broader normative and policy context. Clearly, the Legal Adviser need not and should not disclose predecisional legal deliberations, which may jeopardize client confidences or bona fide executive secrets. Legal opinions justifying covert action are obviously matters of particular sensitivity, involving discretion. And on occasion, there may be a need for a "cooling off" period after a policy decision has been implemented before full public disclosure of the legal rationale seems prudent. But as Professor Dakota Rudesill argues, there is and should be a

30. See, e.g., Stephen W. Preston, The Legal Framework for the United States' Use of Military Force Since 9/11, at the Annual Meeting of the American Society of International Law in Washington, D.C. (Apr. 10, 2015), http://www.defense.gov/News/Speeches/Speech-View/Article/606662 ("Although a certain degree of secrecy is of course required to protect our country, the Administration has demonstrated its commitment to greater transparency in matters of national security and, specifically, in explaining the bases, under domestic and international law, for the United States' use of military force abroad. We have seen this in the President's own speeches, for example, at the National Archives in May 2009, at National Defense University in May 2013, and at West Point in May 2014. Among senior Administration lawyers, we saw this early on, in a speech by the State Department's Legal Adviser at ASIL in March 2010 - this same meeting, five years ago-and in later speeches by the Attorney General at Northwestern in March 2012, and by my predecessor as DoD General Counsel at Yale and at Oxford, both in 2012 [and ... .] by the CIA General Counsel in remarks at Harvard Law School in April 2012. My remarks here today are the latest in the series - an update of sorts-addressing the legal authority for U.S. military operations as the mission has evolved over the past year or so.").

31. Koh, Eight Decades, supra note 1, at 1757-60. 
powerful government presumption against "secret law." 32 When a final policy decision has been made and deemed lawful within the executive branch for a particular set of reasons, prompt public disclosure of that legal analysis should be the norm, not the exception. The default rule should be that in time, executive branch legal opinions would be public and published, with whatever redactions may be necessary to protect genuinely classified facts.

By so urging, I am endorsing something distinct from the so-called "front-page rule," which was recently endorsed by the President's Review Group on surveillance issues:

$\mathrm{Th}[\mathrm{e}]$ informal precept, long employed by the leaders of US administrations, . . . that we should not engage in any secret, covert, or clandestine activity if we could not persuade the American people of the necessity and wisdom of such activities were they to learn of them as the result of a leak or other disclosure.

The Legal Adviser's Duty to Explain extends further than such a prudential rule, which essentially advises U.S. government officials not to do anything that they could not defend in public. The Duty to Explain calls for regular and routine open articulation of the legal rationale underlying particular policy decisions. This strategy allows the administration's legal arguments to be debated and gain legitimacy with the relevant publics, reassuring them that the United States remains committed to acting consistently with the rule of law. For example, Charlie Savage of the New York Times recently reported that four government lawyers who gave legal advice regarding the targeted killing of Osama bin Laden decided:

We should memorialize our rationales [in writing] because we may be called upon to explain our legal conclusions, particularly if the operation goes terribly badly... . We won't have time to articulate them with any care after the fact, and we want to show that this was not post hoc rationalization. And it will further discipline our thinking, and confirm that there is consensus, to write it down. ${ }^{34}$

Now that the existence of these secret legal opinions has been widely reported, these same arguments would seem to cut in favor of the U.S. government releasing the opinions supporting the killing of bin Laden. ${ }^{35}$

The precise content of the public legal explanation will differ from case to case. At a minimum, the content should be sufficient to assure the reader as to why the United States government has concluded that its action is legal under both domestic and international law. Admittedly, open articulation of a public international law rationale does not always settle the distinct issue of domestic legal rationale and only begins a public dialogue that may never be conclusively resolved. But as noted above, the Duty to Explain is particularly

32. Dakota S. Rudesill, Coming to Terms with Secret Law, 7 HARV. NAT'L SECURITY J. (forthcoming 2015).

33. See President's Review Group on Intelligence and Communications Technologies, Liberty and Security in a Changing World 170 (Dec. 12, 2013), http://justsecurity.org/wp-content/uploads/2013 /12/2013-12-12 rg_final_report.pdf; Marty Lederman, The "Front Page Rule," JuST SECURITY BloG (Dec. 30, 2013, 9:40 AM), http://justsecurity.org/5184/front-page-rule (noting the report's endorsement of the rule and related media and practitioner discussion).

34. See, e.g., Charlie Savage, Power Wars: Inside Obama's Post-9/11 Presidency 263 (2015) (quoting then-CIA General Counsel Stephen Preston) (emphasis omitted).

35. See, e.g., id. at 260-66. 
important for international law arguments, given the central, constitutive role that international law assigns to state practice. Customary international legal norms can only be formed from a combination of state practice consistent with the norm plus opinio juris (opinio juris sive necessitates): a belief by states that they are following the norm out of a sense of legal obligation, not just because of reciprocity, comity, morality, or political expediency. To capture this sense of legal obligation, Article 38 of the Statute of the Court of International Justice famously observed: "The Court, whose function is to decide in accordance with international law such disputes as are submitted to it, shall apply... international custom, as evidence of a general practice accepted as law." ${ }^{36}$

In these pages, Professor Rebecca Ingber, a former State Department attorney, astutely described how executive branch interpretations of international law often turn on the timing and the nature of the "interpretation catalyst" ${ }^{37}$ - the event that triggers the interpretation. Professor Ingber argued that whether and how the executive branch asserts an interpretation of its obligations and authority under domestic or international law depends critically upon the point at which that legal question makes entry into the intragovernmental decision-making process. The scope, breadth, flexibility, and even substance of the executive branch's position regarding its legal authority may differ markedly depending on whether the context that first flags the question for dispositive legal decision is, for example, litigation, a national presentation to an international human rights body, or a public speech. Because executive branch legal positions, once taken, tend to be sticky, these "interpretation catalysts," or interpretation-forcing events, become critical triggering moments that often decisively shape the executive's legal and policy decision-making processes.

Interpretation catalysts arise most urgently and can affect the greatest change in times of crisis. The substantive interpretations of international law that emerge reflect a repeated interplay between legal substance and what I have called "transnational legal process. ${ }^{38}$ By demanding better legal process to produce better legal substance, legal advisers can help their policymaker clients develop a better policy option during times of crisis.

Perhaps the best-known, most extensively studied historical example from U.S. practice has been the 1962 Cuban Missile Crisis. ${ }^{39}$ Once U.S. overflights observed Soviet Missiles inside Cuba, three unpalatable policy options were presented for presidential decision: do nothing, undertake a ground invasion (which was both illegal and controversial after the disastrous Bay of Pigs fiasco), or launch a unilateral military strike. Through intensive consultation with senior policymakers via the so-called "ExComm process," State Department Legal Adviser Abram Chayes, his Deputy Leonard Meeker,

36. Statute of the International Court of Justice art. 38, June 26, 1945, 59 Stat. 1055, 33 U.N.T.S. 993 (emphasis added).

37. Rebecca Ingber, Interpretation Catalysts and Executive Branch Legal Decisionmaking, 38 YALE J. INT'L L. 359 (2013).

38. Koh, supra note 22, at 2603.

39. See generally CHAYES, supra note 29 (discussing the Cuban Missile Crisis in great detail). 
and Assistant Attorney General for the Office of Legal Counsel Norbert Schlei helped formulate a fourth option: a defensive "quarantine" approved by the Organization of American States (OAS). ${ }^{40}$ At the time, the defensive quarantine option was roundly excoriated by international law scholars as too closely resembling a "blockade," which would have required Security Council approval under Article 42 of the U.N. Charter. ${ }^{41}$ But the quarantine approach facilitated better policy, inasmuch as it walked the fine line between doing nothing and avoiding nuclear conflict, while spurring back-channel negotiations that brought the crisis to a stable conclusion. For that reason, over a half-century, it has come to be seen not only as a reasonable international legal interpretation but also as a legal opinion that facilitated the best policy option. $^{42}$

Over the last half-century, participants have detailed exactly how the legal opinion in the Cuban Missile Crisis emerged. On October 19, 1962, the United States government learned that Soviet missiles were in Cuba. At 7:00 p.m. Eastern Standard Time that evening, Deputy Legal Adviser Leonard Meeker delivered a paper to Secretary of State Dean Rusk's office concluding that: (1) what was taking place in Cuba was not an "armed attack" against the United States justifying measures of self-defense under Article 51 of the U.N. Charter; (2) that, under the Rio Treaty of 1947, the Council of the OAS could recommend that member states take measures to deal with the action as a threat to "the peace of America," with such a recommendation qualifying as action by a "regional organization" under Chapter VIII of the U.N. Charter, and hence not a violation of the prohibition on the use of force contained in U.N. Charter Article 2(4); and (3) that harkening back to an October 1937 speech where President Franklin Delano Roosevelt proposed a "quarantine of the patients,"43 the naval interdiction of further Soviet missiles carrying missile components to Cuba should not be called a "blockade," which implied belligerency or a state of war, but rather a lawful "defensive quarantine." Although President Kennedy did not detail his legal rationale in his famous speech on the night of October $22,{ }^{44}$ Legal Adviser Chayes offered a full public version of the legal reasoning in the State Department Bulletin about a month later. ${ }^{45}$

40. See generally id. at 14-16 (discussing the legal debate around the "defensive quarantine" concept).

41. See, e.g., Quincy Wright, The Cuban Quarantine, 57 AM. J. INT'L L. 546 (1963) (discussing Article 42 of the United Nations Charter, which calls on the Security Council to "take such action by air, sea, or land forces as may be necessary to maintain or restore international peace and security[, which] may include demonstration, blockade, and other operations by air, sea, or land forces of Members of the United Nations.")

42. See, e.g., Peter Spiro, Remembering Abe Chayes on the Cuban Missile Crisis, OPINIO JURIS (Oct. 22, 2012), http://opiniojuris.org/2012/10/22/remembering-abe-chayes-on-the-cuban-missile -crisis ("The quarantine decision might seem legally anodyne to us . . . but it was controversial at the time."). See generally Graham Allison \& Philip Zelikow, Essence of DECISION: EXPLAINING the CuBAN Missile Crisis (1971); ChAYES, supra note 29; ROBERT F. KENNEDY, THIRTEEN DAYS: A MEMOIR OF THE CUBAN MISSILE CRISIS (1969).

43. Franklin D. Roosevelt, "Quarantine" Speech (Oct. 5, 1937), in 1 PUBLIC PAPERS AND ADDRESSES OF FRANKLIN D. ROOSEVELT 406, 410 (1941).

44. Radio and Television Report to the American People on the Soviet Arms Build-Up in Cuba, 2 Pub. Papers 806 (Oct. 22, 1952).

45. Abram Chayes, Law and the Quarantine of Cuba, 41 FOREIGN AFF. 550 (1963) 
As a law professor, Chayes later provided a detailed insider's account of how law had importantly constrained and channeled three key decisions made during the crisis: the choices (1) whether to use a "quarantine," in lieu of another response; (2) whether to seek an authorizing resolution from the OAS; and (3) how to manage relations with the United Nations. In particular, Chayes showed that the law was both a constraint upon and a justification for these actions and provided the organizational structures within which these policy decisions were made. Chayes concluded that the constraining force of Article 2(4) of the U.N. Charter significantly channeled the ultimate decision away from an air strike or ground invasion and toward the eventual solution of a defensive quarantine. Most relevant for present purposes, he argued for both the intrinsic necessity and the instrumental wisdom of public legal justification for this important and difficult foreign policy decision.

As an intrinsic matter, Chayes accepted Attorney General Robert Kennedy's claim that "moral" considerations influenced the United States's choice to avoid an air or ground invasion. "[L]egal norm and moral precept," he argued, "are two expressions of the same deep human imperative." 46 As an instrumental matter, he observed that the international organizations to which a nation resorts for moral and material support are both influenced by and shape global public legal justification. Key American decision-makers thus "knew it would be desirable to offer a strong legal justification for their action" ${ }^{, 47}$ and that a global perception of legality would be a significant factor "in generating support for and neutralizing opposition to the United States." 48 Thus, when Soviet Ambassador Zorin told the U.N. Security Council, "I am not in an American court of law, and therefore do not wish to answer a question put to me in the manner of a prosecuting counsel," U.S. Ambassador Adlai Stevenson retorted, "You are in the courtroom of world opinion right now."49

To be persuasive, a public explanation of why a national decision comports with international legal norms must explain both the requisite legal processes and the legal standards offered to justify the decision. Because pivotal decisions set crucial precedents, it is essential that the public justification explain why relevant legal standards better support the option chosen over other possible policy options. For example, Chayes describes the United States's repeated confirmation that the "mere emplacement of groundto-ground Soviet missiles in Cuba was not an armed attack warranting use of force in self-defence," reasoning that U.S. adoption of such an expansive notion would trivialize the effort at legal justification and weaken objective legal

(containing a reprint of remarks first published in the State Department Bulletin). Chayes reports that a Legal Adviser's Memorandum, reprinted as Appendix III to his book, was the "contemporaneous official exposition of the [U.S.] government's legal position ... prepared over the night and morning of 22-23 October 1963." CHAYES, supra note 29, at 47. While it was not initially published, the memorandum "became something of a best-seller," with some one thousand copies being distributed to foreign governments and the press. Id. at $47-48$.

46. CHAYES, supra note 29 , at 40 .

47. $I d$. at 68 .

48. Id. at 85 .

49. See, e.g., ABram Chayes et al., 2 InTernational Legal. Process 1101 (1968). 
restraints on the use of force. ${ }^{50}$

To take a second example, in May 1970, Legal Adviser John Stevenson gave an important speech outlining the Nixon Administration's position on the international legal justification for its military operations in Cambodia. ${ }^{51}$ As Stevenson explained,

It is important for the Government of the United States to explain the legal basis for its actions, not merely to pay proper respect to the law, but also because the precedent created by the use of armed forces in Cambodia by the United States can be affected significantly by our legal rationale. ${ }^{52}$

As an historical matter, the legal correctness of Stevenson's speech has been significantly challenged, ${ }^{53}$ but by laying out the Administration's legal theory in a public forum, Stevenson made clear not only what legal authority the United States was claiming but also what policy discretion the United States was not claiming. By so doing, he gave American citizens and legislators, as well as the international legal community, a fuller opportunity to assess the U.S. legal theory and to test the government's actions in light of it.

Stevenson's Cambodia opinion is only one of many issued by the State Department Legal Advisers over the years. ${ }^{54}$ Admittedly, as time has passed, other U.S. government legal offices have also begun to opine on international legal issues. For example, in 1980, the Office of Legal Counsel of the Justice Department accomplished an admirable feat of legal transparency, when it published-with a detailed introduction and summary-the twenty-five legal opinions that office had issued over the fifteen-month period that encompassed the Iranian Hostages Crisis, many of them referencing important analyses of international law. ${ }^{55}$ But as Scharf and Williams note:

Where a significant international law-related issue came within the special purview of these other legal offices, the State Department lawyers are ordinarily expected to work with their counterparts (and vice versa) through a "clearance process" in an attempt to ensure that a single legal position would emerge. Where this proved not possible, divergent legal opinions are presented to the President and Cabinet within the text of a decision memo....

In such non-consensus situations, "the Principals," or even the President himself, end up choosing which legal rationale they intend to follow. One recent prominent example of President Obama-himself a former teacher of constitutional law-choosing a controlling opinion from among divergent legal

50. CHAYES, supra note 29, at 23. Chayes notes that the United States declined to advance a self-defense rationale because to do so could not credibly have legitimated U.S. conduct and "would have signaled that the United States did not take the legal issues involved very seriously." $I d$. at 66.

51. John R. Stevenson, Statement of the Legal Adviser, 64 AM. J. INT'L L. 933 (1970).

52. Id. at 935 .

53. See, e.g., Richard A. Falk, The Cambodian Operation and International Law, 65 AM. J. INT'L L. 1 (1971).

54. For other examples, see generally SCHARF \& WILLIAMS, supra note 1.

55. 4A OPINIONS OF THE OFFICE OF LEGAL COUNSEL 71-333 (1980). I should disclose here that, under the supervision of Theodore B. Olson and Larry L. Simms, I worked on the compilation and production of that special opinion volume, and the drafting of the Introduction and Summary, as an attorney-advisor at the Office of Legal Counsel.

56. SCHARF \& WILLIAMS, supra note 1, at 211. 
views within his administration came when the United States continued its joint military operation in Libya in $2011^{57}$

But history indicates that some of the most controversial legal positions taken by the U.S. government occurred in cases in which L was cut out of the decision-making process: "the 1980s mining of Nicaraguan harbors and armed support for the 'contras,' the 1990 kidnapping of Dr. Alvarez-Machain from Mexico, and . . the adoption of the initial policies related to treatment of 'unlawful enemy combatants' detained in the aftermath of the attacks on 9/11.".58

When, as in these notorious cases, ${ }^{59}$ other legal offices that may be less sensitive than the State Department to international legal and diplomatic communities opine on difficult questions of international law, they may not show sufficient awareness of the long-term precedential implications of their interpretations.

Mindful of this historical record, as the State Department's Legal Adviser during the first term of the Obama Administration, representing then-Secretary of State Hillary Rodham Clinton I tried to fulfill the Legal Adviser's Duty to Explain in a variety of ways. These included speeches at the annual meeting of the American Society of International Law, ${ }^{60}$ congressional testimony, ${ }^{61}$ lectures and articles, ${ }^{62}$ arguments and presentations before international legal

57. See Charlie Savage, 2 Top Lawyers Lost to Obama in Libya War Policy Debate, N.Y. TIMES (June 17, 2011), http://www.nytimes.com/2011/06/18/world/africa/18powers.html. For further discussion of that debate, see generally Harold Hongju Koh, The War Powers and Humanitarian Intervention, 53 Hous. L. REV. No. 4 (forthcoming 2016) (20th Annual Frankel Lecture Symposium, with commentary by Professors Dawn Johnsen and Ashley Deeks).

58. SCHARF \& WILLIAMS, supra note 1, at 211-12. By way of comparison, Sir Frank Berman, a former UK Legal Adviser, noted:

Probably the most notorious incident where the UK Legal Adviser was deliberately cut out of the loop was the 1956 Suez invasion. ... [But now i]t is considered a cardinal sin within the UK Foreign Office to put up a policy submission that did not clearly recite that the Legal Adviser or his staff had been consulted, or which did not include an analysis of the legal questions which were relevant to the decision. Id. at 212 .

59. For discussion of the mining of the harbors of Nicaragua during the Reagan Administration, which was undertaken by the CIA without input from the Legal Adviser's Office, see id. at 60 (recounting the recollections of Davis Robinson, the Legal Adviser from 1981 to 1985). For discussion of the Alvarez-Machain case, see id. at 92-93. For discussion of L's exclusion from the issue of legal treatment of detainees after $9 / 11$, see $i d$. at 129-30 (recounting the recollections of William $\mathrm{H}$. Taft IV, the Legal Adviser from 2001 to 2005, criticizing a January 9, 2002, memorandum by John Yoo, then-Deputy Assistant Attorney General of the Office of Legal Counsel at the Department of Justice, as "seriously flawed" and noting that the Justice Department conclusions "are actually incorrect as well as incomplete."); and id. at 2.

60. See, e.g., Koh Remarks at ASIL, supra note 2; Harold Hongju Koh, Statement Regarding Syria, U.S. DEP'T OF STATE (Mar. 30, 2012), http://www.state.gov/s/1/releases/remarks/187163.htm.

61. See, e.g., Libya and War Powers: Hearing Before the S. Comm. on Foreign Relations, 112th Cong. (2011) (statement of Harold Hongju Koh, Legal Adviser, U.S. Department of State) [hereinafter Koh Libya Testimony]; Harold Hongju Koh, Statement Regarding Use of Force in Libya, U.S. DEP'T OF STATE (Mar. 26, 2011 ), http://www.state.gov/s/l/releases/remarks/159201.htm.

62. Harold Hongju Koh, Foreign Official Immunity After Samantar: A United States Government Perspective, 44 VAND. J. TRANSNAT'L L. 1141 (2011); Harold Hongju Koh, International Criminal Justice 5.0, 38 YALE J. INT'L L. 525 (2013); Harold Hongju Koh, International Law in Cyberspace, 54 HARV. INT'L L.J. 1 (2012); Harold Hongju Koh, Remarks: Twenty-First Century International Lawmaking, 101 GEO. L.J. 725 (2012); Harold Hongju Koh \& Todd F. Buchwald, The Crime of Aggression: The United States Perspective, 109 AM. J. INT'L L. 257 (2015). The most recent two, published after I left office, nevertheless represented cleared U.S. government positions. 
and human rights bodies, ${ }^{63}$ and, at times, blog posts regarding important international legal events. ${ }^{64}$ In offering these public explanations, I saw my audience as not just the general public, the media, and the academic community but also "the invisible college of Legal Advisers." This "invisible college" includes other government lawyers from international law-respecting nations, who need to explain to their own government clients whether or not to support the U.S. legal justification for its actions in cutting-edge situations, for example, with respect to the use of armed drones or cyber conflict.

Finally, almost as important as the legal analysis offered is a complete statement of the contemporaneous facts on which the legal opinion is based. Outsiders cannot fully evaluate the lawfulness of any state's conduct until they know the precise factual circumstances under which it chooses to take action. Controversial legal opinions are often issued under severe time pressure and based on information that is fast-changing and only partially available to the general public. Twenty-four hours can bring radical changes in the relevant facts. Accordingly, it is especially important that the public legal rationale carefully distinguish the legal question-given the stated facts, is the policy option being considered available to policymakers under domestic or international law?-from the policy question: under these factual circumstances, would it be wise for policymakers to resort to that option?

Given the multiplicity of legal actors within any government, a government's legal rationale may sometimes be gleaned from several sources. But what ultimately matters is not from which office the explanation emanates, but that at some publicly available place there be a complete version of the "official legal story." Thus, I do not believe that the requirement of a public Duty to Explain is met, for example, by having unnamed "senior government officials" leak talking points to newspaper reporters or the blogosphere. In order for the legal arguments to be understood, analyzed, and contested by knowledgeable lawyers and commentators, it is crucial that the government issue and "own" a public legal analysis as the government's official legal

63. See Harold Hongju Koh, Reflections on the Law and Politics of the Kosovo Case, in THE LAW AND POLITICS OF THE KOSOVO ADVISORY OPINION 350 (Marko Milanović \& Michael Wood eds., 2015).

64. See, e.g., Harold Hongju Koh, The Lawfulness of the U.S. Operation Against Osama bin Laden, OPINIO JURIS (May 19, 201 1, 6:00 AM), http://opiniojuris.org/201 1/05/19/the-lawfulness-of-the -us-operation-against-osama-bin-laden. Other positions that 1 did not publicly release were nevertheless found and released by the media after I left office. See, for example, Memorandum Opinion on the Covenant Against Torture and Its Application in Situations of Armed Conflict from Harold Hongju Koh, Legal Adviser, U.S Dep't of State (Jan. 21, 2013), https://www.documentcloud.org/documents/1053901 -state-department-cat-memo.html, which was discussed in Charlie Savage, U.S. Seems Unlikely to Accept That Rights Treaty Applies to Its Actions Abroad, N.Y. TIMES (Mar. 6, 2014), http://www .nytimes.com/2014/03/07/world/us-seems-unlikely-to-accept-that-rights-treaty-applies-to-its-actions -abroad.html; see generally Marko Milanovic, Harold Koh's Legal Opinions on the US Position on the Extraterritorial Application of Human Rights Treaties, EJIL:TALK! (Mar. 7, 2014), http://www.ejiltalk .org/harold-kohs-legal-opinions-on-the-us-position-on-the-extraterritorial-application-of-human-rights -treaties; and Memorandum Opinion on the Geographic Scope of the International Covenant on Civil and Political Rights from Harold Hongju Koh, Legal Adviser, U.S Dep't of State (Oct. 19, 2010), https:/www.documentcloud.org/documents/1053853-state-department-iccpr-memo.html.

65. Cf. Oscar Schachter, The Invisible College of International Lawyers, 72 Nw. U. L. REV. 217 (1977) (describing the professional community of professors, students, government officials, and international civil servants who focus on international legal issues). 
position in every difficult or important case.

To illustrate, take one recent area where I believe that the United States has failed to fulfill its Duty to Explain: the collective use of humanitarian force. In 1999, NATO famously took military action in Kosovo against Serbian atrocities, without express Security Council authorization. As Sir Adam Roberts noted, Kosovo perplexed

[1]awyers [who] tend to like a world of clarity, where an action can be distinctly categorised as legal or illegal .... [But i]n reality, because contradictory principles were inescapably at the heart of this crisis, there was no definitive legal answer that could satisfy a convincing majority of the world's peoples, governments or even international lawyers. ${ }^{66}$

As U.S. Assistant Secretary of State for Democracy, Human Rights and Labor during Kosovo, I watched as nineteen NATO members accepted the legality of some form of humanitarian intervention without U.N. Security Council approval.

In October 1998, the United Kingdom publicly declared the legality of the operation, "so long as the proposed use of process is necessary and proportionate to the [humanitarian] aim and is strictly limited in time and scope to this aim." ${ }^{77}$ Seventeen other NATO members individually satisfied themselves of the legality of their participation in the operation. ${ }^{68}$ But curiously, the United States government never articulated a legal justification condoning its NATO actions, instead relying upon an amorphous listing of factors that together justified the intervention as a matter of policy. ${ }^{69}$ ThenSecretary-General Kofi Annan captured the United Nations' ambiguity about a narrowly tailored form of humanitarian intervention in situations of great extremis by issuing a statement that recognized occasions when force might be necessary, catalyzing the ongoing international legal movement to explore affirmatively whether there is an international Responsibility to Protect (R2P). ${ }^{70}$

The Clinton Administration's failure to articulate a clear legal rationale for its Kosovo intervention came back to haunt the Obama Administration fourteen years later, when the United States again failed to adequately to discharge its Duty to Explain. The Obama Administration received unmistakable proof that the Syrian leader Assad had launched a deliberate chemical assault on innocent civilians after President Obama had warned that

66. See Adam Roberts, NATO's 'Humanitarian War' over Kosovo, 41 SURVIVAL 102, 105 (1999). See generally Koh, supra note 57 (discussing this issue in detail).

67. UK FOREIGN \& COMMONWEALTH OFFICE, FRY/KOSOVO: THE WAY AHEAD; UK VIEW ON THE LEGAL BASE FOR USE OF FORCE (Oct. 7, 1998).

68. See, e.g., the Oral Pleadings of the Kingdom of Belgium before the International Court of Justice in Legality of Use of Force (Serb. v. Belg.), Verbatim Record (May 10, 1999, 3 p.m.) (arguing that NATO's use of force was lawful). See generally Roberts, supra note 66, at 104.

69. See Michael J. Matheson, Justification for the NATO Air Campaign in Kosovo, 94 AM. SOC'Y INT'L L. PROC. 301 (2000).

70. See Chelsea O'Donnell, The Development of the Responsibility to Protect: An Examination of the Debate Over the Legality of Humanitarian Intervention, 24 DUKE J. COMP. \& INT'L L. 557, 56063 (2013). 
such an act would cross a "red line.", Significantly, President Obama had announced four years earlier in his December 2009 Nobel Prize acceptance speech that "I believe that force can be justified on humanitarian grounds, as it was in the Balkans, or in other places that have been scarred by war." 2013, the question became how best to back up those words with meaningful, lawful action. The Arab League endorsed international action but shied away from approving "all necessary measures," making it difficult to invoke the U.N. Charter Article 52 "regional organizations" route to skirting a Russian veto that had been famously deployed during the Cuban Missile Crisis. ${ }^{73}$ The British Attorney General issued a post-Kosovo legal opinion indicating that humanitarian intervention without Security Council resolution could be lawful under international law, but the Prime Minister failed to secure parliamentary support for intervention. ${ }^{74}$

Faced with this weak support abroad and at home, President Obama pushed the pause button not once, but twice: first saying on August 30, that instead of using the previously threatened military force, he would seek prior approval from a distracted and divided Congress when he plainly had not secured the necessary House votes. Three weeks later, he postponed indefinitely that congressional vote-which he likely would have lost-in order to pursue diplomatic alternatives that remain ongoing. ${ }^{75}$

To my knowledge, the only public legal position the U.S. Government offered on the legality of intervention in Syria was a quote by the White House Counsel to the New York Times, which explained that, while an attack on Syria "may not fit under a traditionally recognized legal basis under international law," given the novel factors and circumstances, such an action would nevertheless be "justified and legitimate under international law" and so not prohibited. ${ }^{76}$ As a matter of domestic law, the Administration also apparently concluded that congressional approval was not required: "administration lawyers decided that it was within Mr. Obama's constitutional authority to carry out a strike on Syria as well, even without permission from Congress or the Security Council, because of the 'important national interests' of limiting regional instability and of enforcing the norm against using chemical

71. President Barack Obama, Remarks by the President to the White House Press Corps (Aug. 20, 2012), https://www.whitehouse.gov/the-press-office/2012/08/20/remarks-president-white-house -press-corps.

72. President Barack Obama, Nobel Lecture: A Just and Lasting Peace (Dec. 10, 2009), http:// www.nobelprize.org/nobel prizes/peace/laureates/2009/obama-lecture_en.html.

73. Major Powers Hold UN Talks on Syria, AL JAZEERA AMERICA (Aug. 28, 2013), http:/america.aljazeera.com/articles/2013/8/28/uk-to-asksecuritycounciltoauthorizenecessarymeasuresin syria.html.

74. Joshua Rosenberg, Syria Intervention: It May Not Be Wise, But Using Force May Be Lawful, GUARDIAN (Aug. 28, 2013), http://www.theguardian.com/law/2013/aug/28/syria-intervention -force-lawful.

75. Ernesto Londoño, Obama says U.S. Will Take Military Action Against Syria, Pending Congress 's Approval, WASH. POST (Aug. 31, 2013), https://www.washingtonpost.com/world/national -security/obama-set-to-speak-on-syria-in-rose-garden/2013/08/31/65aea2 10-125b-1 1 e3-85b6 -d27422650fd5_story.html.

76. Charlie Savage, Obama Tests Limits of Power in Syrian Conflict, N.Y. Times (Sept. 8, 2013), http:/www.nytimes.com/2013/09/09/world/middleeast/obama-tests-limits-of-power-in-syrian -conflict.html (quoting White House Counsel Kathy Ruemmler). 
weapons." 77 The White House Counsel stated that

[t] he president believed that it was important to enhance the legitimacy of any action that would be taken by the executive . . to seek Congressional approval of that action and have it be seen, again as a matter of legitimacy both domestically and internationally, that there was a unified American response to the horrendous violation of the international norm against chemical weapons use. ${ }^{78}$

Plainly, a legal opinion of such significance should have been laid out somewhere other than in a newspaper quote. Given the importance of the issue, the Obama Administration failed to fulfill its Duty to Explain by not issuing a detailed legal opinion elaborating the White House view. Threatening military action in Syria without stating a public legal rationale creates a dangerous precedent. As Abram Chayes argued after the Cuban Missile Crisis, "[f]ailure to justify in terms of international law warrants and legitimizes disapproval and negative responses from other governments participating directly in the process." ${ }^{79}$ In the future, other less-humanitarian minded states can cite President Obama's 2013 threat to put their own broad spin on the legal interpretation using the murky concepts of humanitarian intervention and R2P for their own self-interested purposes. In both the Kosovo and Syria cases, the President's lawyers should have explained-not just in lay terms, as President Obama himself did, but in legal language that international lawyers can debate (as the United Kingdom's Attorney General did in Syria and in Kosovo) how humanitarian intervention without a Security Council resolution could be lawful under international law. ${ }^{80}$

\section{ANSWERING OBJECTIONS}

Let me respond to three basic arguments that have been offered against a public Duty to Explain: first, that when facts are classified, the need for secrecy overwhelms the need for public explanation of the government's legal rationale; second, that there are cutting-edge situations-for example, Responsibility to Protect (R2P) - where it may be better to offer no legal rationale at all but instead to call the action "illegal, but legitimate"; and, third, that at important times, the Legal Adviser's duty of loyalty to his or her client may trump the Duty to Explain and militate against public disclosure of legal advice.

The first common argument offered against public explanation is that the operation under consideration may be covert or that key facts may be classified. But recently, State Department attorney Alexandra Perina comprehensively rebutted that claim by clarifying how international law-making processes are negatively affected when a state acts covertly and that covert conduct later

77. Id.

78. Id.

79. CHAYES, supra note 29 , at 44 .

80. André Nollkaemper, Intervention in Syria and International Law: Inside or Out?, OPINIO JURIS (Sept. 1, 2013), http://opiniojuris.org/2013/09/01/syria-insta-symposium-andre-nollkaemper -intervention-syria-international-law-inside; see also Koh, supra note 57 (outlining such an argument). 
comes to public light. ${ }^{81}$ Perina acknowledges that states may act covertly for a range of legitimate political, diplomatic, and strategic reasons and that, at times, covert behavior may be consistent with international law. But she argues that "covert actors" non-engagement in public discourse distorts the landscape of evidence that informs other actors' legal judgments." Where states view their conduct as lawful, acting covertly diminishes their ability to reinforce or develop the law, "ceding that ground to third parties." 82 Thus, for example, the acting state cedes to the media the task of developing the public factual narrative that drove the action.

Take, for example, the highly publicized case of Anwar Al Aulaqi, a key leader of Al Qaeda in the Arabian Peninsula (AQAP) who was reported killed in September 2011. ${ }^{83}$ Initially, the Obama Administration refused to acknowledge its role in the death, even while releasing numerous public facts about Al Aulaqi's leadership role in furtherance of attacks on American citizens. $^{84}$ But after resisting for two years acknowledging its role in the lethal action, the U.S. government finally acknowledged a role in his death and offered a legal justification. By then, widespread and often inaccurate claims had been made about the lack of limits on the Administration's theory of when it was lawful to use a drone to target a U.S. citizen-leader of an opposing terrorist force. The net result was that the U.S. government's legal case was made late - and, in important senses, inaccurately-by piecemeal release of a mosaic of legal arguments. Far preferable would have been a thorough and authoritative recitation of the facts and legal arguments comprising the U.S. government's legal case for deploying a particular counterterrorism technique. At one point, the Administration released a sanitized White Paper that presented the legal arguments without accompanying facts. ${ }^{85}$ But the problem with this approach, as Perina notes, is that "there may be legitimate skepticism about the credibility and weight that statements of legal principle can bear when sanitized of facts and divorced from acknowledged conduct - that is, whether they are merely "cheap talk." "\$6 Perhaps worst of all, the absence of a contemporaneous public legal explanation can give the impression that the President is claiming broader, more flexible, and far-reaching authority than he actually intends, permitting commentators and even presidential candidates to assert inaccurately that the President was asserting a right to kill Americans with drones, anywhere, anytime, including on U.S. soil. ${ }^{87}$ Future decision-

81. Alexandra H. Perina, Black Holes and Open Secrets: The Impact of Covert Action on International Law, 53 COLUM. J. TRANSNAT'L L. 507 (2015).

82. Id. at 507.

83. See generally ScotT Shane, OBjective Troy: A TERrorist, A President, AND the RISE OF THE DRONE (2015); see also Savage, supra note 34, at 233-54 (discussing legal memos regarding Al Aulaqi).

84. Perina, supra note 81 , at 544.

85. U.S. DEP'T OF JUSTICE, WHITE PAPER, LAWFULNESS OF A LETHAL OPERATION DIRECTED Against a U.S. CITIZEN Who IS A SENIOR OPERATIONAL LEADER OF AL-QA'ida OR AN ASSOCIATED FORCE 1-2 (Nov. 8, 2011) [hereinafter DOJ WHITE PAPER], http://www.justice.gov/sites/default/files /oip/legacy/2014/07/23/dept-white-paper.pdf.

86. Perina, supra note 81 , at 559 n.200.

87. Transcript: Rand Paul's Filibuster of John Brennan's CIA Nomination, L.A. TIMES (Mar. 
makers need to know the facts on which particular opinions are based, so that they can analogize from precedents and note when a prior decision may not provide good precedent for a current problem.

By 2014, a federal appeals court had found that the U.S. government's official disclosure of its legal White Paper in the Al Aulaqi case amounted to a waiver of privilege about its legal theory underlying certain lethal counterterrorism operations. ${ }^{88}$ The court accordingly ordered the U.S. government to disclose parts of a highly classified Justice Department legal memorandum. The net result was that the U.S. government made its legal case too little, too late. It was forced to release, three years after the fact, a legal opinion that it could have made public at the time that the lethal action had first become widely known. By refusing to do so, it missed the critical opportunity to build domestic and international support for its international legal position. Nor did the claim of needed secrecy strengthen the persuasiveness of the U.S. government's legal arguments. To the contrary, the implication was that the U.S. did not come clean because it had something to hide. As Perina notes,

\begin{abstract}
Unacknowledged conduct has an inherently corrosive effect on the law by casting doubt on whether the operative legal rules have obligatory effect, potentially contributing to the rules' desuetude .... [Thus, even as] States continue ... often legitimately, to act covertly and maintain secrecy over aspects of their conduct .... [they must] understand the legal consequences and costs of secrecy and covertness, in order to manage their programs more strategically and potentially mitigate some of the pernicious effects [of secrecy] on the law.
\end{abstract}

A second objection to a public Duty to Explain is that some action-such as the humanitarian intervention in Kosovo-is better justified not as lawful per se, but rather, as "illegal but legitimate." ${ }^{90}$ This argument strikes me as a failure of lawyerly responsibility, which we would never accept in other legal situations. After all, do courts tell ambulance-drivers who run red lights to prevent deaths that their actions are illegal because they might encourage ambulance-chasers to do the same thing? Did we tell same-sex or different-race couples that if they marry, they should consider those statuses permanently "illegal but legitimate"? Did we tell battered spouses that if they protect themselves in self-defense that their self-protective actions are "illegal but legitimate"? The answer, of course, is no. Instead, in such difficult circumstances where the law is ill-defined, we use the lessons of history to help define the contours of an emerging lawful exception to an overly rigid prohibition. In the case of a justified violation of a traffic rule, for example, responsible lawyers craft a narrow "affirmative defense" that would render lawful otherwise illegal behavior.

7, 2013), http://articles.latimes.com/2013/mar/07/news/la-pn-transcript-rand-paul-filibuster-20130307 (quoting Senator Rand Paul's incorrect assertion that the President's theory "[t]hat Americans could be killed [by a drone] in a café in San Francisco or in a restaurant in Houston or at the home in Bowling Green, Kentucky").

88. N.Y. Times v. Dep't of Justice, 752 F.3d 123 (2d Cir. 2014).

89. Perina, supra note 81 , at 508.

90. See, e.g., Michael Ignatieff, How to Save the Syrians, N.Y. REV. OF Books (Sept. 13, 2013), http://www.nybooks.com/blogs/nyrblog/2013/sep/13/how-save-syrians/. 
To be concrete, such an approach should have been taken by the United States with regard to the lawful uses of humanitarian intervention. I have detailed elsewhere how a lawful way to use force in Syria could have been found under both domestic and international law. ${ }^{91}$ Like former British Legal Adviser Sir Daniel Bethlehem, I believe that "[i]n the case of the law on humanitarian intervention, an analysis that simply relies on the prohibition of the threat or use of force in Article 2(4) of the U.N. Charter and its related principles of non-intervention and sovereignty, is overly simplistic." 92 In Kosovo, by comparison, without formally embracing NATO's legal position, Professor Louis Henkin enumerated four factors that would support the legality of collective military action in exceptional circumstances, e.g., without Security Council authorization: extreme gravity of the human rights situation, collective humanitarian action, prior Security Council unavailability, and subsequent Council monitoring. ${ }^{93}$ As Professor Henkin noted at the time, these are "lawmaking moments," when instead of ducking public explanation, our governments should address such questions head-on, as the British government did with respect to the legality of humanitarian intervention in both Kosovo and Syria. $^{94}$

A third unpersuasive argument lodged against a public Duty to Explain international legal positions is that it would create a conflict of interest with the private Duty of Loyalty that a government lawyer necessarily owes to his clients and ministers. I do not deny that a tension sometimes arises, but in my experience, rarely does it rise to the level of actual conflict of interest. Admittedly, there may be times when the doctrines of attorney-client privilege, executive privilege, or deliberative process privilege may weigh against immediate public disclosure of a legal rationale, particularly if forces are at risk or facts on the ground are rapidly changing. ${ }^{95}$ But this is only an argument for keeping government legal opinions secret temporarily, not permanently.

As a public official who swears a solemn oath to uphold the Constitution and law of the United States, the Legal Adviser owes broader loyalties than just to his or her immediate policy clients. With respect to international law, the

91. See, e.g., Koh, supra note 57; Harold Hongju Koh, Syria and the Law of Humanitarian Intervention (Part I: Political Miscues and U.S. Law), JUST SECURITY BLOG (Sept. 26, 2013), https://www.justsecurity.org/1158/koh-syria; Harold Hongju Koh, Syria and the Law of Humanitarian Intervention (Part II: International Law and the Way Forward), JUST SECURITY BLOG (Oct. 2, 2013), https://www.justsecurity.org/1506/koh-syria-part2; Harold Hongju Koh, Syria and the Law of Humanitarian Intervention', Part III - A Reply, JUST SECURITY BLOG (Oct. 10, 2013), https://www .justsecurity.org/1863/syria-law-humanitarian-intervention-part-iii-reply/. Much of the discussion in text derives from the preceding sources.

92. Daniel Bethlehem, Stepping Back a Moment - The Legal Basis in Favour of a Principle of Humanitarian Intervention, EJIL:T ALK! (Sept. 12, 2013), http://www.ejiltalk.org/stepping-back-a-moment -the-legal-basis-in-favour-of-a-principle-of-humanitarian-intervention/.

93. Louis Henkin, Editorial Comments, NATO's Kosovo Intervention: Kosovo and the Law of Humanitarian Intervention, AM. J. INT'L L. 824, 826 (1999) ("Is it better to leave the law alone, while turning a blind eye (and a deaf ear) to violations that had compelling moral justification? Or should Kosovo move us to push the law along to bring it closer to what the law ought to be?').

94. Id. at 827 .

95. For a comparative law discussion of privileges associated with government legal advice, see Matthew Windsor, Government Legal Advisers Through the Ethics Looking Glass, in LAW IN Politics, Politics in LAW (David Feldman ed., 2013). 
need to establish opinio juris cuts in favor of legal advisers explaining their clients' international legal positions to a broad array of external constituencies: Congress, the public, foreign governments, intergovernmental organizations, and nongovernmental organizations. Having the President's own lawyers personally and publicly delivering the Administration's legal position makes crystal clear that politically accountable decision-makers, not just the career civil servants, have concluded that their government's action comports with the rule of law.

A legal adviser's greatest tension comes in balancing loyalties: loyalty to clients and felt duties to the international law the lawyer is sworn to uphold. Legal advisers seek to bring a blend of independence, expertise, and creativity in solving problems and promoting the rule of law. The task of promoting multilateralism is woven into the fabric of the legal adviser's daily work. Legal advisers are, by their nature, engaged in multiple dialogues: conversations with foreign colleagues about common problems and multilateral solutions; interagency conversations about international law with colleagues across their national government; conversations with the legal academy and learned societies, such as the American Society of International Law; and internal conversations with office colleagues that promote repeated examination of the office's precedents and practices. The legal adviser's greatest challenge is to balance the imperatives of politics and law and to make legal judgments that are politically savvy without becoming overly politicized. As in the Cuban Missile Crisis, skilled government lawyers can help identify lawful channels through which difficult policy decisions can flow and to shape legal instruments through which policy goals can be pursued.

In the end, as Legal Adviser, I tried to follow two commonsense rules. The first is commonly known as "the airplane rule": to be in on the landing, the legal adviser must be "in at the takeoff" of any new foreign policy episode in order to help establish the legal and political legitimacy of the actions that follow. ${ }^{96}$ As Abe Chayes once explained, law is not self-activating; for law to influence meaningfully the path of government decision, the lawyers must be brought in early, and then kept in the loop:

[I]t was very important for both the validity of the [U.S. government's] decision, the subsequent justification, and the mobilization of support that the legal considerations were taken fully into account during the decision-making process. Somebody did not just make the decision and then call the lawyer in and ask the lawyer to cook up some sort of legal theory to defend it. ${ }^{97}$

The second rule is what Harvard President Derek Bok once called "the

96. See SCHARF \& WiLliamS, supra note 1, at 60 (quoting Davis Robinson saying "I would argue strongly that if $\mathrm{L}$ had been involved in the take-off in the case of the mining of the harbors of Managua, we could have provided constructive advice ... The input of $L$ would, I believe, have added a significant dimension to the decision-making process and also improved the implementation of the President's ultimate decision. However, as it transpired, instead of being ready for the fire storm that followed the public disclosure of the mining of the harbors, the Administration was legally caught offguard. Thus, all that the lawyers could contribute was assistance in after-the-fact containment of a train wreck."). 480 (1997)

97. Living History Interview with Abram Chayes, 7 TRANSNAT'L L. \& CONTEMP. ProBs. 459, 
pinball rule": if pinball players do not shake the machine, he said, they are not really playing. But if they tilt the machine, they are not good players either. So the rule the best players follow is "shake it, but don't tilt it." The same applies here. For government legal advisers, this means proactively engaging and constantly challenging the policy process, but striving not to bring the policy process to a screeching halt unless the law requires it.

\section{CONCLUSION}

All of this is easier said than done and better illustrated in practice than in theory. Lessons learned in the crucible cast important light on what it means to be a government lawyer committed to the rule of law in international affairs. Legal advisers engage in an endlessly interactive process between lawyers and policymakers and between nations and international institutions. One fellow legal adviser cogently called the government lawyer's fundamental duties: "Fearless advice; Loyal implementation." academic work, "transnational legal process," legal doctrine and rules transform from abstraction to reality. ${ }^{99}$ Law influences policy, policy makes law, and that perpetual feedback loop helps explain how government lawyers help their nations obey international law.

Foreign policy decisions most fully conform with international law when international lawyers are "at the table" while important decisions are being made. If international relations are to be more than just power politics, international lawyers must fuse their training and skill with moral fortitude and guide the evolution of transnational legal process with the application of reasoned and respect-worthy legal norms. By having the courage to argue with their clients and counterparts, to invoke illegality when appropriate; and to offer creative legal solutions that enable better policy options, legal advisers help defend their countries when challenged while at the same time helping those countries to live up to their own best standards and principles. ${ }^{100}$ But as they sit at the decision-making table, legal advisers are both strengthened and disciplined by knowing that they will be expected to discharge the nation's Duty to Explain the legal rationale for its actions and can expect to be held accountable for those public explanations.

98. See Alan Kessel, former Canadian Legal Adviser, Remarks at 2015 British Institute of International and Comparative Law Conference (Feb. 26, 2015) (described in note $†$ supra).

99. See, e.g., Harold Hongju Koh, The 1998 Frankel Lecture: Bringing International Law Home, 35 Hous. L. REv. 623, 626 (1998); Harold Hongju Koh, Transnational Legal Process, 75 NEB. L. REV. 181 (1996).

100. As Abe Chayes once put it, there is "nothing wrong" with a lawyer-whether inside or outside of government-- "holding the United States to its own best standards and principles." David E. Rosenbaum, Abram Chayes, John Kennedy Aide, Dies at 77, N.Y. TIMES (Apr. 18, 2000), http://www.nytimes.com/2000/04/18/us/abram-chayes-john-kennedy-aide-dies-at-77.html. 
